\title{
Unfavorable Outcomes Following Surgical Treatment of Hallux Valgus Deformity
}

\author{
A Systematic Literature Review \\ Alexej Barg, MD, Joshua R. Harmer, BS, Angela P. Presson, PhD, Chong Zhang, MS, Mellanye Lackey, MSI, and \\ Charles L. Saltzman, MD \\ Investigation performed at the Department of Orthopaedics, University of Utah, Salt Lake City, Utah
}

\begin{abstract}
Background: Surgical correction of deformity plays a central role in the treatment of hallux valgus deformity. However, complications or unintended outcomes are frequently noted in clinical series. There has been no rigorous systematic review of studies reporting outcomes of surgical treatment for hallux valgus deformity, to the best of our knowledge.
\end{abstract}

Methods: We performed a systematic review of studies reporting the outcomes of surgical correction for hallux valgus deformity.

Results: A total of 229 studies met the inclusion criteria. The pooled rates of postoperative patient dissatisfaction and postoperative first metatarsophalangeal pain were $10.6 \%$ and $1.5 \%$, respectively. The overall rate of recurrent deformity was $4.9 \%$.

Conclusions: Hallux valgus surgery has been reported to have fairly consistent results and rates of complications or unfavorable outcomes.

Level of Evidence: Therapeutic Level IV. See Instructions for Authors for a complete description of levels of evidence.

$\mathrm{H}$ allux valgus (HV) deformity is one of the most common foot disorders ${ }^{1,2}$. The pooled prevalence of HV deformity in the reported literature has been estimated to be $23 \%$ among those 18 to 65 years of age and $35.7 \%$ among those over 65 years of age ${ }^{3}$. The pathogenesis of HV deformity is complex ${ }^{4}$. Surgical correction of deformity plays a central role in the treatment of HV deformity, and $>100$ different surgical techniques have been described ${ }^{5,6}$.

The more commonly reported unintended outcomes from surgical correction of $\mathrm{HV}$ include recurrence of $\mathrm{HV}$ deformity $^{7,8}$, persistent pain ${ }^{9}$, secondary metatarsalgia ${ }^{7}$, nerve injury $^{7,10}$, infection ${ }^{10,11}$, delayed union or nonunion ${ }^{12}$, hallux varus deformity ${ }^{7,8,11}$, and the need for secondary procedures ${ }^{7,11}$. Dissatisfaction and the need for hardware removal are also frequently noted in clinical series, with rates of up to $47 \%{ }^{13}$ and $25 \%{ }^{14}$, respectively.
While each of these individual surgical outcomes has been highlighted in independent clinical series ${ }^{5}$, to the best of our knowledge no rigorous systematic review of studies reporting the outcomes of surgical treatment of HV deformity has been published. The objectives of our study were to (1) describe the characteristics of studies of surgical HV deformity treatment, (2) determine patient dissatisfaction and pain, (3) determine the rates of postoperative complications by surgery type, and (4) identify correlations between preoperative or intraoperative factors and rates of postoperative complications.

\section{Materials and Methods}

Search Method and Strategy

D RISMA (Preferred Reporting Items for Systematic reviews and Meta-Analyses) guidelines were followed when preparing

Disclosure: This investigation was supported in part by the National Center for Research Resources and the National Center for Advancing Translational Sciences, National Institutes of Health, through grant 5UL1TR001067-02 (formerly 8UL1TR000105 and UL1RR025764). On the Disclosure of Potential Conflicts of Interest forms, which are provided with the online version of the article, one or more of the authors checked "yes" to indicate that the author had a relevant financial relationship in the biomedical arena outside the submitted work (http://links.Iww.com/JBJS/E889). 
TABLE I Inclusion and Exclusion Criteria for the Systematic Literature Review

\begin{tabular}{|ll|}
\hline \multicolumn{1}{|c|}{ Inclusion Criteria } & \multicolumn{1}{c|}{ Exclusion Criteria } \\
\hline $\begin{array}{l}\text { Reporting of clinical, surgical, and/or radiographic outcomes } \\
\text { Reporting of surgical complications }\end{array}$ & Review article \\
Minimum follow-up $\geq 1$ year or median follow-up $\geq 2$ years & Case report \\
Minimum 10 feet reported on & Surgical technique article \\
Identification of specific surgical procedure(s) used & Cadaveric study \\
$\begin{array}{l}\text { English, German, French, Italian, Norwegian, Russian, } \\
\text { Spanish, or Swedish language }\end{array}$ & Biomechanical/kinematic study \\
& Patient-oriented educational article (e.g., "why not to wear high heels") \\
& Double publication involving the same patient cohort \\
& $\begin{array}{l}\text { Primarily adolescent-onset HV patient cohort, defined as inclusion of patients } \\
<18 \text { years old or mean patient age <25 years }\end{array}$ \\
Inclusion of patients with spasticity (stroke, cerebral palsy, etc.)-induced HV \\
Inclusion of patients treated for hallux rigidus or metatarsophalangeal \\
osteoarthritis \\
Inclusion of patients with rheumatoid or inflammatory arthritis, gout, or hemophilia \\
Inclusion of patients who underwent surgery outside the first ray \\
Revision of failed HV surgery \\
Prosthetic replacement of first metatarsophalangeal joint
\end{tabular}

this systematic literature review ${ }^{15}$. Five major medical databases were searched from inception through July 1, 2016: PubMed, MEDLINE, Embase, CINAHL (Cumulative Index to Nursing and Allied Health), and the Cochrane Central Register of Controlled Trials (CENTRAL). We also searched the "gray" literature (conference proceedings, industry white papers, Google Scholar). A medical library search strategist (M.L.) was consulted to develop a sensitive and comprehensive search strategy (see Appendix Table E-1). Supplemental bibliographic reference searches were also conducted by 2 of the reviewers (A.B. and J.R.H.) to identify potentially relevant studies.

\section{Study Selection and Data Extraction Procedure}

The study selection process was conducted independently by 3 reviewers (A.B., J.R.H., and C.L.S.). If a study passed an initial screening on the basis of the title and abstract review, the full text was retrieved and reviewed in detail to determine if the study met inclusion and exclusion criteria (Table I). The decision to include or exclude the study was made on the basis of a group consensus.

Data were extracted from studies that met the abovementioned inclusion/exclusion criteria independently by the 2 reviewers (A.B. and J.R.H.). Data extraction was verified by a third reviewer (C.L.S.). The following data were extracted from each study: author(s), journal of publication, title, publication year, study design (prospective versus retrospective, singlecenter versus multicenter, observational versus comparative), type of surgical procedure, number of subjects and/or number of feet, sex distribution, subject age, follow-up duration, percentage of subjects and/or feet available at the latest follow-up, and preoperative radiographic parameters (HV angle, intermetatarsal angle). The following data elements regarding unfavorable outcomes were also extracted from each study: patient dissatisfaction (see Appendix Table E-2), recurrence of HV deformity, postoperative pain (visual analog scale [VAS], $\geq 5$ ), postoperative metatarsalgia, nerve injury, infection, nonunion, iatrogenic hallux varus, reoperation, and removal of hardware.

\section{Study Design}

A total of 229 studies (reporting on 266 patient cohorts) met the inclusion criteria (see Appendix Table E-3) and are the focus of the present systematic review. The studies were published between 1968 and 2016 (Table II). For multiple studies by the same authors, only 1 study was included unless clear information on the absence of overlap between the cohorts was available.

TABLE II Study Designs for the 266 Included Patient Cohorts

\begin{tabular}{|lc|}
\hline \multicolumn{1}{|c|}{ Design } & No. (\%) \\
\hline Prospective & $63(23.7 \%)$ \\
Retrospective & $203(76.3 \%)$ \\
Single center & $260(97.7 \%)$ \\
Multicenter & $6(2.3 \%)$ \\
Observational & $191(71.8 \%)$ \\
Comparative & $75(28.2 \%)$ \\
Level of evidence & \\
I & $22(8.3 \%)$ \\
II & $13(4.9 \%)$ \\
III & $55(20.7 \%)$ \\
IV & $176(66.2 \%)$ \\
\hline
\end{tabular}


The Journal of Bone \& Joint Surgery $\cdot$ JbjS. org Volume 100-A · Number $18 \cdot$ September 19, 2018

Unfavorable Outcomes Following Surgical Treatment of Hallux Valgus Deformity

TABLE III Criteria Used for the Modified Coleman Methodology Score

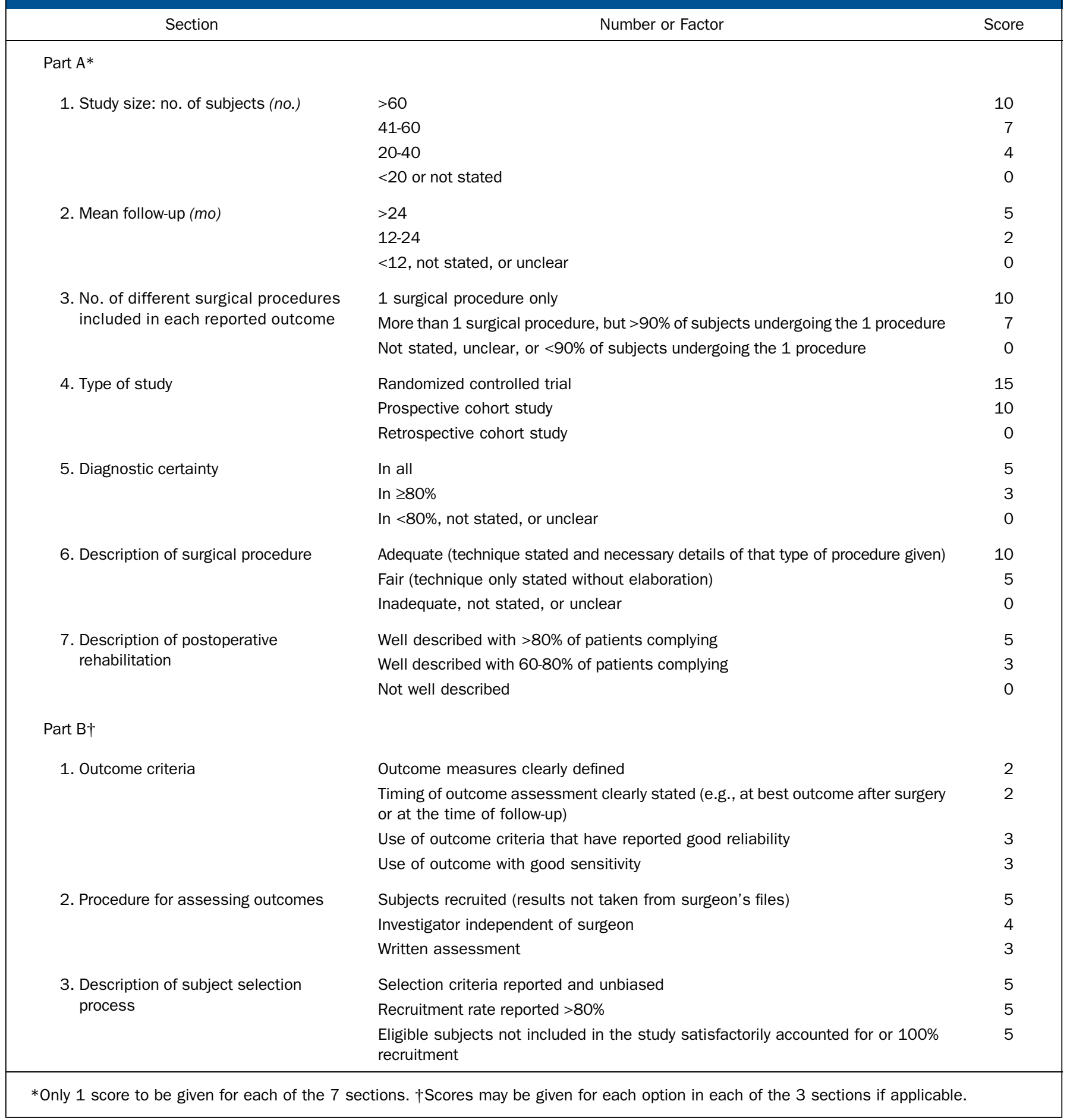

\section{Study Quality Evaluation}

Two reviewers (A.B. and J.R.H.) applied a modified version of the Coleman methodology score (mCMS) to assess the quality of methodology in each study ${ }^{16,17}$. The 2-part mCMS grades studies on the basis of 10 criteria (Table III). Part A evaluates the study size, mean follow-up duration, number of different surgical procedures, type of study, diagnostic certainty, and descriptions of the surgical procedure and postoperative rehabilitation. Part B evaluates the outcome criteria, procedure for assessing outcomes, and description of the subject selection 
The Journal of Bone \& Joint Surgery $\cdot$ JBjS. org

Unfavorable Outcomes Following Surgical Treatment of Volume 100-A · Number $18 \cdot$ September 19, 2018

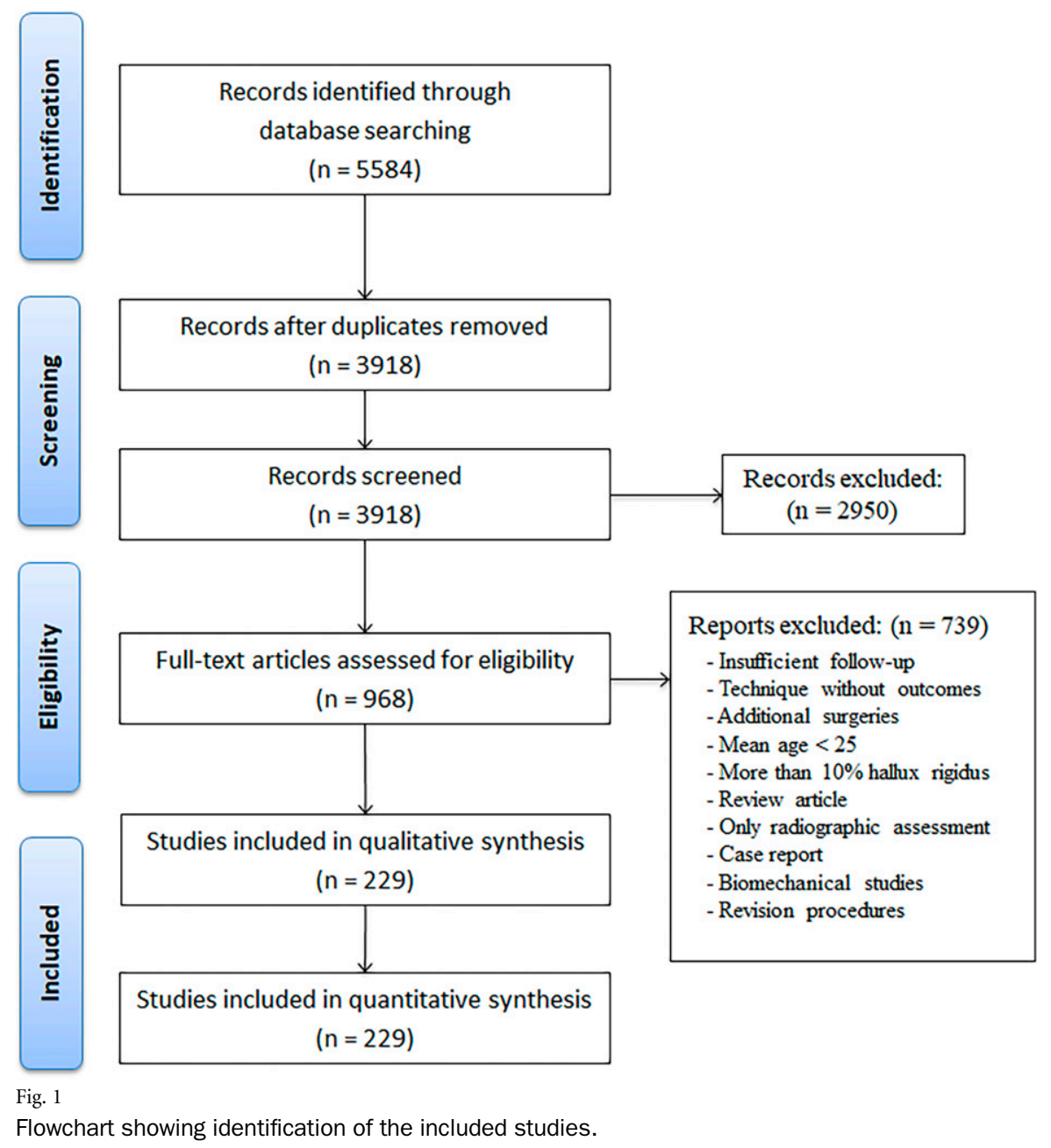

process. The maximum score on the mCMS is 100, which indicates that a study largely avoids chance, biases, and confounding factors ${ }^{18}$. The CMS is a validated, reliable scoring system ${ }^{16}$.

\section{Statistical Methods}

The study type (prospective versus retrospective), number of patients, number of feet, patient age and sex, and follow-up duration were summarized across the 9 surgery types. The percentage of female patients was estimated using an inverse-variance weighting method, and patient age and follow-up duration were summarized using a simple weighted average because the majority of studies did not report the variance.

A chi-square $\mathrm{Q}$ test for heterogeneity was used to test for differences across surgery types for average rates of patient dissatisfaction, HV deformity recurrence, reoperation, removal of hardware, nonunion, intraoperative nerve injury, postoperative infection, persisting pain (VAS $\geq 5$ ), and postoperative metatarsalgia. Time-to-event information was ignored for these outcomes because of an absence of consistent reporting. Outcome estimates for each surgery type were transformed and pooled across studies using the inverse-variance weighting method implemented using the metaprop function of the meta package in $\mathrm{R}^{19}$. The arcsine transformation was used to handle rare events for which some studies did not contribute any affected patients ${ }^{20}$. A random-effects model was used in which

\begin{tabular}{|c|c|c|c|}
\hline \multirow[b]{2}{*}{ Surgery Type } & \multicolumn{3}{|c|}{$\mathrm{mCMS}$} \\
\hline & Part A & Part B & Total \\
\hline Distal osteotomy & 45.7 & 27.5 & 73.2 \\
\hline Proximal osteotomy & 43.3 & 29.4 & 72.9 \\
\hline Shaft osteotomy & 48.7 & 29.9 & 78.2 \\
\hline Joint hemiresection & 40.4 & 24.5 & 64.9 \\
\hline Simple bunionectomy & 41.7 & 26.2 & 67.8 \\
\hline Shaft and Akin osteotomies & 44.5 & 28.3 & 72.8 \\
\hline Proximal and Akin osteotomies & 44.6 & 27.3 & 71.9 \\
\hline First TMT arthrodesis & 43.4 & 29.4 & 72.9 \\
\hline Other & 39.2 & 25.8 & 65.1 \\
\hline
\end{tabular}


TABLE V Descriptive Summary of Cohort Characteristics by Surgery Type

\begin{tabular}{|c|c|c|c|c|c|c|}
\hline Surgery Type & No. of Patients & No. of Feet & $\begin{array}{l}\text { Prospective/ } \\
\text { Retrospective }\end{array}$ & $\begin{array}{c}\text { Mean Age } \\
\text { (Range)* (yr) }\end{array}$ & $\begin{array}{c}\text { \% Female Patients } \\
\qquad(95 \% \mathrm{Cl}) \dagger\end{array}$ & $\begin{array}{l}\text { Mean Follow-up } \\
\text { (Range) } \neq(y r)\end{array}$ \\
\hline Distal osteotomy & 6,765 (52.6\%) & 8,809 (54.1\%) & $35 / 89$ & $47.1(11.0-87.0)$ & 73.5 (70.7-76.1) & $3.9(0.5-34.0)$ \\
\hline Shaft osteotomy & $1,028(8.0 \%)$ & $1,154(7.1 \%)$ & $10 / 12$ & 50.9 (11.0-83.0) & $79.2(70.9-85.6)$ & $2.5(1.0-10.1)$ \\
\hline Joint hemiresection & $882(6.9 \%)$ & $1,136(7.0 \%)$ & $1 / 21$ & $55.7(16.0-87.0)$ & $72.2(65.3-78.2)$ & $5.8(0.5-26.0)$ \\
\hline $\begin{array}{l}\text { Shaft and Akin } \\
\text { osteotomies }\end{array}$ & 497 (3.9\%) & $555(3.4 \%)$ & $3 / 7$ & $52.2(13.4-78.0)$ & $79.2(70.4-85.9)$ & $4.1(1.0-11.7)$ \\
\hline $\begin{array}{l}\text { Proximal and Akin } \\
\text { osteotomies }\end{array}$ & $380(3.0 \%)$ & $482(3.0 \%)$ & $1 / 6$ & $50.3(14.0-83.0)$ & 76.7 (66.1-84.7) & $1.9(1.0-5.0)$ \\
\hline $\begin{array}{l}\text { First TMT } \\
\text { arthrodesis§ }\end{array}$ & 271 (2.1\%) & 309 (1.9\%) & $2 / 4$ & $44(12.0-84.0)$ & $72.6(61.9-81.2)$ & $3.9(1.0-12.0)$ \\
\hline
\end{tabular}

between-study variance was estimated using the DerSimonianLaird method ${ }^{21}$. A 95\% confidence interval (CI) was included with each estimate.

We examined risk of bias across studies by testing for differences in study characteristics including publication year, level of evidence, and total mCMS across surgery types. We compared publication year and level of evidence across surgery types using a chi-square test with Monte Carlo stimulation because of low cell counts and across total mCMS using analysis of variance (ANOVA). Because these characteristics could bias our results comparing patient outcomes across surgery types, we repeated our analyses controlling for study characteristics by meta-regression implemented using the metareg function of the meta package in $\mathrm{R}$ (adjusted $\mathrm{p}$ value, $\mathrm{p}_{\text {adj }}$ ). We also tested for heterogeneity of the studies within each surgery type using the chi-square $\mathrm{Q}$ test described above and determined the percentage of study variation due to heterogeneity rather than chance $\left(\mathrm{I}^{2}\right)$.

We used meta-analysis techniques to pool outcomes within surgery types and to test for outcome differences across surgery types. However, it is important to emphasize that these

TABLE VI Rate of Postoperative Patient Dissatisfaction by Surgery Type

\begin{tabular}{|c|c|c|c|c|c|c|}
\hline Surgery Type & $\begin{array}{l}\text { No. of Studies } \\
\qquad(N=139)\end{array}$ & $\begin{array}{l}\text { No. of Patients } \\
(\mathrm{N}=6,414)\end{array}$ & $\begin{array}{c}\text { Total No. of } \\
\text { Patients Affected }\end{array}$ & $\begin{array}{c}\% \text { of Patients } \\
\text { Affected }(95 \% \mathrm{Cl})\end{array}$ & $1^{2}$ & P Value* \\
\hline Distal osteotomy & $65(46.8 \%)$ & 3,502 (54.6\%) & 357 & $9.5(7.1-12.2)$ & $80 \%$ & $<0.001$ \\
\hline Shaft osteotomy & $12(8.6 \%)$ & $340(5.3 \%)$ & 38 & $8.9(3.6-16.3)$ & $80 \%$ & $<0.001$ \\
\hline Joint hemiresection & $17(12.2 \%)$ & 697 (10.9\%) & 133 & $16.1(10.8-22.3)$ & $80 \%$ & $<0.001$ \\
\hline $\begin{array}{l}\text { Proximal and Akin } \\
\text { osteotomies }\end{array}$ & $2(1.4 \%)$ & 201 (3.1\%) & 14 & $6.9(3.9-10.9)$ & $0 \%$ & 0.9 \\
\hline First TMT arthrodesis $\neq$ & $2(1.4 \%)$ & $120(1.9 \%)$ & 12 & $10(5.3-16)$ & $0 \%$ & 1 \\
\hline Other§ & 7 (5.0\%) & 289 (4.5\%) & 22 & $5.8(2.5-10.3)$ & $50 \%$ & 0.1 \\
\hline
\end{tabular}


The Journal of Bone \& Joint Surgery $\cdot$ JBJS.org Volume 100-A · Number $18 \cdot$ September 19, 2018

Unfavorable Outcomes Following Surgical Treatment of Hallux Valgus Deformity

\section{TABLE VII Rate of Persisting Postoperative Pain (VAS $\geq 5$ ) by Surgery Type}

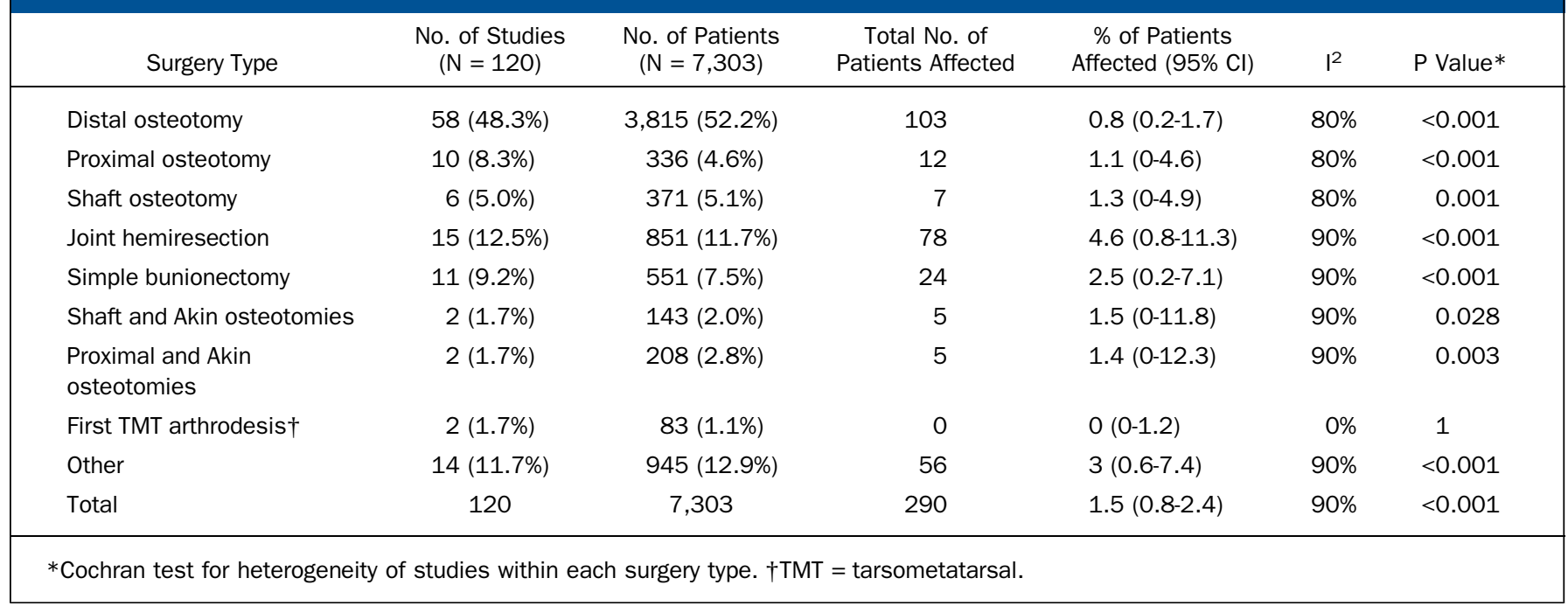

analyses were conducted within the context of a systematic review. The studies synthesized here were highly heterogeneous and reported on just 1 to 2 surgery types each, and thus we were unable to perform a traditional meta-analysis that pools effect sizes for comparisons of 2 surgery types. Similarly, we were unable to assess publication bias.

The HV angle and first-second intermetatarsal angle were compared with outcomes (average rates of HV deformity recurrence, patient dissatisfaction, and pain VAS 25 ) using a weighted Pearson correlation coefficient, with weights corresponding to study size. Corresponding 95\% CIs were estimated using the Fisher $\mathrm{z}$ transformation, and $\mathrm{p}$ values were calculated using permutation tests. Statistical analyses were conducted in $R$ version 3.3.1, significance was assessed at the 0.05 level, and all tests were 2-tailed.

\section{Results}

The study selection process is shown in Figure 1. A total of 16,273 procedures on 12,866 patients from 229 studies were included in the data analysis (see Appendix Table E-3). The mCMS for the included cohorts was comparable in all subgroups, ranging between 64.9 and 73.2 (Table IV). A descriptive summary of the cohort characteristics is shown in Table V.

Postoperative Patient Dissatisfaction and Postoperative Pain Patient satisfaction was assessed using dichotomous ( $\mathrm{n}=47$; $33.8 \%)$, ordinal $(n=89 ; 64.0 \%)$, or interval $(n=3 ; 2.2 \%)$ scales (see Appendix Table E-2). There was a significant difference in the rate of patient dissatisfaction across the 9 different surgery types $\left(p=0.004 ; p_{a d j}=0.03\right)($ Table VI). The

\section{TABLE VIII Rate of Postoperative Metatarsalgia by Surgery Type}

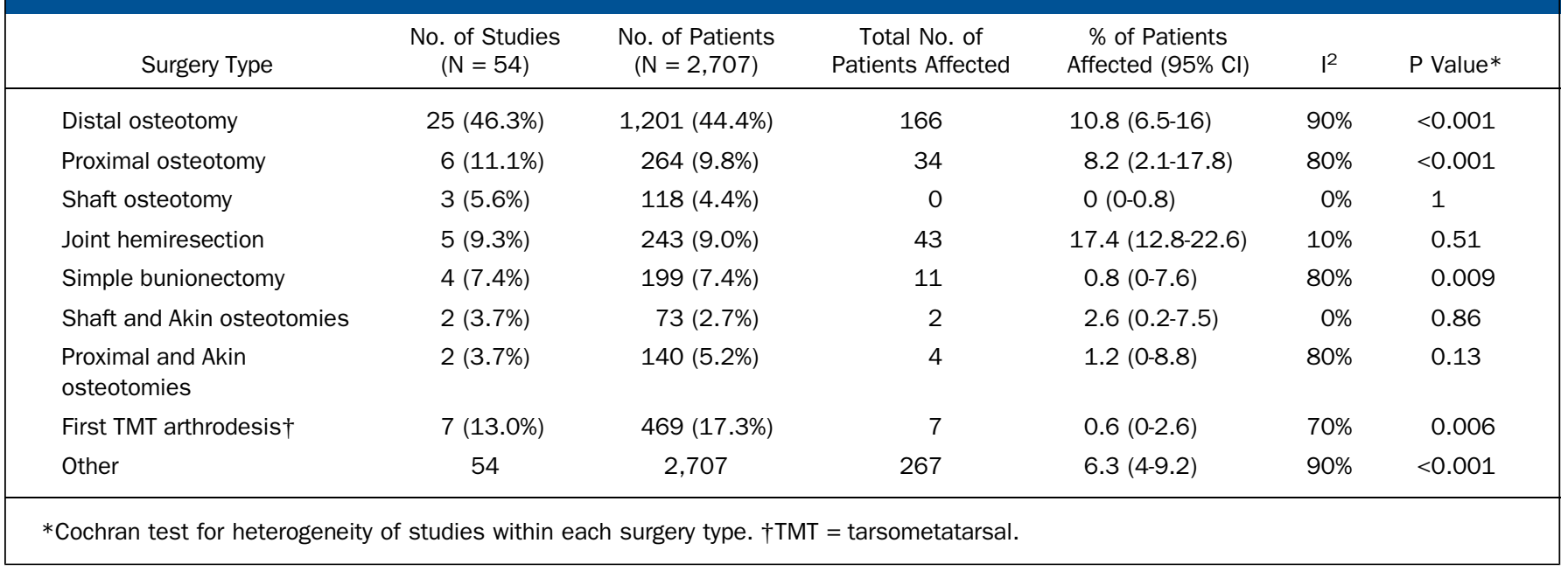


The Journal of Bone \& Joint Surgery $\cdot$ JbjS. org Volume 100-A · Number $18 \cdot$ September 19, 2018

Unfavorable Outcomes Following Surgical Treatment of Hallux Valgus Deformity

TABLE IX Rate of Postoperative HV Recurrence by Surgery Type

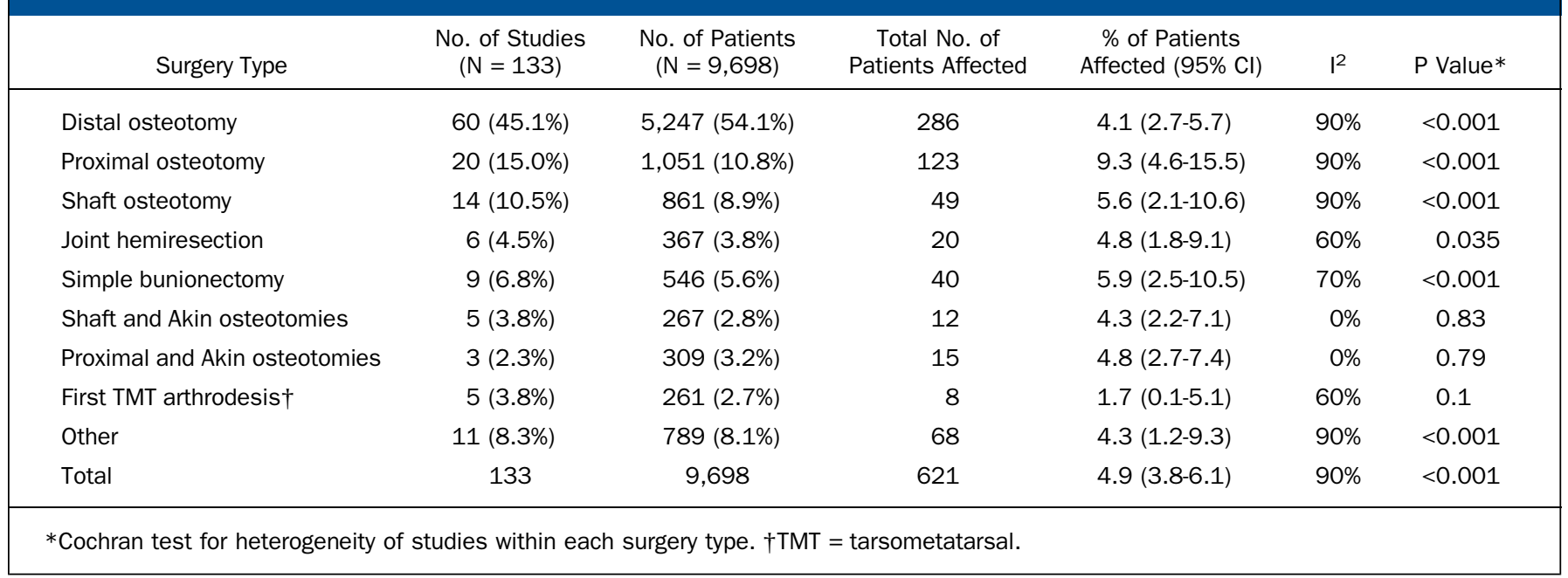

dissatisfaction rate was the highest in patients who underwent a simple bunionectomy or joint hemiresection.

The rate of persisting postoperative pain was comparable in the 9 different surgery types $\left(\mathrm{p}=0.26 ; \mathrm{p}_{\mathrm{adj}}=0.54\right)$ (Table VII). There was a significant difference in the prevalence of postoperative metatarsalgia $\left(\mathrm{p}<0.001 ; \mathrm{p}_{\mathrm{adj}}=0.01\right)$ (Table VIII). The rate of postoperative metatarsalgia was the highest in patients who underwent joint hemiresection.

Recurrence of HV Deformity and Intraoperative Nerve Injury The rate of recurrent $\mathrm{HV}$ deformity was comparable across all surgery types $\left(\mathrm{p}=0.43 ; \mathrm{p}_{\mathrm{adj}}=0.32\right)$, averaging $4.9 \%$ (Table IX).

The rate of intraoperative nerve injury was comparable across all surgery types $\left(\mathrm{p}=0.38 ; \mathrm{p}_{\mathrm{adj}}=0.45\right)$, averaging $3 \%$ (Table X).

\section{Infection and Osseous Nonunion}

There was a significant difference in reported postoperative infection rate across the 9 different surgery types $(\mathrm{p}=0.02$; $\left.\mathrm{p}_{\mathrm{adj}}=0.14\right)($ Table XI). Patients who underwent a first tarsometatarsal arthrodesis (Lapidus procedure) had the highest reported rate of postoperative infection, and patients who had a metatarsal shaft osteotomy had the lowest reported rate.

There was a significant difference in the postoperative rate of osseous nonunion across the 9 different surgery types ( $\mathrm{p}$ $\left.=0.012 ; \mathrm{p}_{\mathrm{adj}}<0.001\right)$ (Table XII). The rate of postoperative nonunion was the highest in patients who underwent first tarsometatarsal arthrodesis.

\section{Need for Secondary Surgery and Postoperative Hallux Varus Deformity}

The rate of reoperation was comparable across all surgery types $\left(\mathrm{p}=0.005 ; \mathrm{p}_{\mathrm{adj}}=0.18\right)($ Table XIII $)$, as was the need for hardware removal $\left(\mathrm{p}<0.001 ; \mathrm{p}_{\mathrm{adj}}=0.08\right)($ Table XIV).

There was a significant difference in the rate of hallux varus deformity across the 9 different surgery types $(p=0.025$; $\left.\mathrm{p}_{\text {adj }}=0.012\right)($ Table XV). The reported rate of postoperative

TABLE X Rate of Intraoperative Nerve Injury by Surgery Type

\begin{tabular}{|c|c|c|c|c|c|c|}
\hline Surgery Type & $\begin{array}{l}\text { No. of Studies } \\
\quad(\mathrm{N}=69)\end{array}$ & $\begin{array}{l}\text { No. of Patients } \\
\qquad(\mathrm{N}=3,930)\end{array}$ & $\begin{array}{c}\text { Total No. of } \\
\text { Patients Affected }\end{array}$ & $\begin{array}{c}\% \text { of Patients } \\
\text { Affected }(95 \% \mathrm{Cl})\end{array}$ & $1^{2}$ & P Value* \\
\hline Distal osteotomy & 40 (58.0\%) & $2,460(62.6 \%)$ & 102 & $3.3(2.2-4.5)$ & $60 \%$ & $<0.001$ \\
\hline Shaft osteotomy & $4(5.8 \%)$ & $120(3.1 \%)$ & 2 & $0.5(0-4)$ & $50 \%$ & 0.16 \\
\hline Joint hemiresection & $4(5.8 \%)$ & 171 (4.4\%) & 4 & $1.8(0.1-5.7)$ & $50 \%$ & 0.2 \\
\hline First TMT arthrodesis $\dagger$ & $4(5.8 \%)$ & 217 (5.5\%) & 15 & $5(0.4-14.1)$ & $80 \%$ & 0.002 \\
\hline Other & 69 & 3,930 & 165 & $3(2-4.1)$ & $70 \%$ & $<0.001$ \\
\hline
\end{tabular}


The Journal of Bone \& Joint SURgery $\cdot$ JBjS.org Volume 100-A • Number $18 \cdot$ SePtember 19, 2018

Unfavorable Outcomes Following Surgical Treatment of Hallux Valgus Deformity

\section{TABLE XI Rate of Postoperative Infection by Surgery Type}

\begin{tabular}{|c|c|c|c|c|c|c|}
\hline Surgery Type & $\begin{array}{l}\text { No. of Studies } \\
\qquad(\mathrm{N}=164)\end{array}$ & $\begin{array}{l}\text { No. of Patients } \\
(\mathrm{N}=10,577)\end{array}$ & $\begin{array}{c}\text { Total No. of } \\
\text { Patients Affected }\end{array}$ & $\begin{array}{c}\% \text { of Patients } \\
\text { Affected }(95 \% \mathrm{Cl})\end{array}$ & $1^{2}$ & P Value* \\
\hline Distal osteotomy & $83(50.6 \%)$ & $6,408(60.6 \%)$ & 188 & $2.5(1.9-3.2)$ & $60 \%$ & $<0.001$ \\
\hline Shaft osteotomy $\dagger$ & $13(7.9 \%)$ & $677(6.4 \%)$ & 13 & $1.5(0.6-2.8)$ & $30 \%$ & 0.21 \\
\hline Joint hemiresection & $10(6.1 \%)$ & $530(5.0 \%)$ & 16 & $2.2(0.6-4.8)$ & $60 \%$ & 0.007 \\
\hline $\begin{array}{l}\text { Proximal and Akin } \\
\text { osteotomies }\end{array}$ & $5(3.0 \%)$ & 329 (3.1\%) & 10 & $2.9(1.3-4.9)$ & $0 \%$ & 0.78 \\
\hline First TMT arthrodesis $キ \S$ & $3(1.8 \%)$ & $179(1.7 \%)$ & 16 & $11.4(0.3-35)$ & $90 \%$ & $<0.001$ \\
\hline Other & 15 (9.1\%) & $821(7.8 \%)$ & 27 & $2.3(0.7-4.9)$ & $70 \%$ & $<0.001$ \\
\hline Total & 164 & 10,577 & 339 & $2.6(2.1-3.2)$ & $60 \%$ & $<0.001$ \\
\hline
\end{tabular}

*Cochran test for heterogeneity of studies within each surgery type. †Surgery type with lowest value. キSurgery type with highest value. $\S \mathrm{TMT}=$ tarsometatarsal.

hallux varus deformity was the highest in patients who underwent a proximal osteotomy.

\section{Correlation Between Radiographic Parameters and Postoperative Outcomes}

The preoperative HV angle was positively correlated with the postoperative rate of $\mathrm{HV}$ deformity recurrence $(\mathrm{r}=0.3,95 \%$ $\mathrm{CI}=0.11$ to $0.47, \mathrm{p}=0.002$ ) (Table XVI). The preoperative first-second intermetatarsal angle was negatively correlated with the postoperative rate of patient dissatisfaction $(\mathrm{r}=-0.26,95 \%$ $\mathrm{CI}=-0.42$ to $-0.09, \mathrm{p}=0.002$ ) (Table XVI). The latter result is interpreted as indicating that patients with lower preoperative first-second intermetatarsal angles were more dissatisfied than patients with higher angles.

\section{Discussion}

We performed a systematic literature review of studies addressing clinical outcomes in adult patients who underwent primary surgical treatment for HV deformity. Five major medical databases were searched from inception through July 1, 2016, and all articles written in English, Spanish, French, German, Italian, Norwegian, Russian, and Swedish were considered for inclusion. Using strict inclusion and exclusion criteria, we identified papers focused on the outcomes of primary treatment of adult HV without known systemic etiology, without contamination by other surgical treatments, and with sufficient follow-up time and information to be able to make meaningful observations. In identifying those essential articles, we reduced the 5,584 papers identified in the database search

TABLE XII Rate of Postoperative Osseous Nonunion by Surgery Type

\begin{tabular}{|c|c|c|c|c|c|c|}
\hline Surgery Type & $\begin{array}{l}\text { No. of Studies } \\
\quad(\mathrm{N}=101)\end{array}$ & $\begin{array}{l}\text { No. of Patients } \\
\qquad(\mathrm{N}=7,526)\end{array}$ & $\begin{array}{c}\text { Total No. of } \\
\text { Patients Affected }\end{array}$ & $\begin{array}{c}\% \text { of Patients } \\
\text { Affected }(95 \% \mathrm{Cl})\end{array}$ & $1^{2}$ & P Value* \\
\hline Distal osteotomy & $61(60.4 \%)$ & 5,489 (72.9\%) & 7 & $0.01(0-0.06)$ & $0 \%$ & 1 \\
\hline Shaft osteotomy $\dagger$ & $6(5.9 \%)$ & $338(4.5 \%)$ & 0 & $0(0-0.28)$ & $0 \%$ & 1 \\
\hline Joint hemiresection $\dagger$ & $2(2.0 \%)$ & $75(1.0 \%)$ & 0 & $0(0-1.28)$ & $0 \%$ & 1 \\
\hline First TMT arthrodesis $£ \S$ & $5(5.0 \%)$ & 261 (3.5\%) & 13 & $3.77(1.14-7.83)$ & $50 \%$ & 0.18 \\
\hline Other & 9 (8.9\%) & $490(6.5 \%)$ & 1 & $0.05(0-0.43)$ & $0 \%$ & 0.96 \\
\hline Total & 101 & 7,526 & 26 & $0.04(0.01-0.1)$ & $0 \%$ & 0.7 \\
\hline
\end{tabular}


The Journal of Bone \& Joint Surgery - Jbjs.org Volume 100 -A · Number $18 \cdot$ September 19,2018

Unfavorable Outcomes Following Surgical Treatment of Hallux Valgus Deformity

\section{TABLE XIII Rate of Reoperation Other Than Hardware Removal by Surgery Type}

\begin{tabular}{|c|c|c|c|c|c|c|}
\hline Surgery Type & $\begin{array}{l}\text { No. of Studies } \\
\quad(\mathrm{N}=92)\end{array}$ & $\begin{array}{l}\text { No. of Patients } \\
(N=6,040)\end{array}$ & $\begin{array}{c}\text { Total No. of } \\
\text { Patients Affected }\end{array}$ & $\begin{array}{c}\% \text { of Patients } \\
\text { Affected }(95 \% \mathrm{Cl})\end{array}$ & $1^{2}$ & P Value* \\
\hline Distal osteotomy & $37(40.2 \%)$ & 3,137 (51.9\%) & 107 & $1.3(0.5-2.4)$ & $80 \%$ & $<0.001$ \\
\hline Shaft osteotomy & 9 (9.8\%) & $515(8.5 \%)$ & 16 & $2.2(0.2-6.3)$ & $80 \%$ & $<0.001$ \\
\hline Joint hemiresection & $4(4.3 \%)$ & 229 (3.8\%) & 6 & $2(0.1-6.1)$ & $60 \%$ & 0.08 \\
\hline $\begin{array}{l}\text { Proximal and Akin } \\
\text { osteotomies }\end{array}$ & $3(3.3 \%)$ & $273(4.5 \%)$ & 15 & $5(0.2-15.5)$ & $90 \%$ & $<0.001$ \\
\hline First TMT arthrodesis $\dagger$ & $5(5.4 \%)$ & $261(4.3 \%)$ & 18 & $6.6(3.9-9.9)$ & $0 \%$ & 0.65 \\
\hline Other & $8(8.7 \%)$ & 366 (6.1\%) & 9 & $2.1(0.9-3.8)$ & $0 \%$ & 0.7 \\
\hline Total & 92 & 6,040 & 225 & $2.1(1.4-3)$ & $70 \%$ & $<0.001$ \\
\hline
\end{tabular}

process to 229 key articles included in the analysis. The total mCMS among the major classes of procedure were between 64 and 74 , which suggests moderate overall methodological quality of the sources.

Based on the major overall findings reported at a mean follow-up of 4 years for the total of 16,273 surgeries, we found an average rate of recurrent deformity of $4.9 \%(95 \%$ CI, $3.8 \%$ to $6.1 \%)$, metatarsalgia of $6.3 \%(95 \% \mathrm{CI}, 4 \%$ to $9.2 \%$ ), dissatisfaction of $10.6 \%$ (95\% CI, $8.8 \%$ to $12.5 \%$ ), and first metatarsophalangeal pain of $1.5 \%$ (95\% CI, $0.8 \%$ to $2.4 \%)$. Although the rate of hardware removal was relatively high for some procedures (16\% for combined shaft and Akin osteotomy procedures), the need for other secondary surgery was relatively low, averaging $2.1 \%$ (95\% CI, $1.4 \%$ to $3 \%$ ). The observed results should be interpreted carefully, especially with regard to the patient dissatisfaction rate.
First, different scales and tools were used to assess patient dissatisfaction rates, including dichotomous, ordinal, and interval scales (see Appendix Table E-2). Second, pooling satisfaction scores for the purpose of review may not yield a reproducible or valid outcome as the majority of instruments generally used to assess satisfaction have demonstrated low evidence with respect to reliability or validity ${ }^{22}$. The average infection rate in analyzed studies was $2.6 \%$ (95\% CI, $2.1 \%$ to $3.2 \%$ ). However, this finding should be carefully interpreted as different definitions for infection were used, without standardized definitions for "wound infections" versus "wound complications."

We were surprised to see that the simple bunionectomy procedure yielded higher relative rates of patient dissatisfaction, perioperative infection, and development of hallux varus. We hypothesize 2 plausible explanations for these

TABLE XIV Rate of Hardware Removal by Surgery Type

\begin{tabular}{|c|c|c|c|c|c|c|}
\hline Surgery Type & $\begin{array}{l}\text { No. of Studies } \\
\quad(N=44)\end{array}$ & $\begin{array}{l}\text { No. of Patients } \\
(\mathrm{N}=2,793)\end{array}$ & $\begin{array}{c}\text { Total No. of } \\
\text { Patients Affected }\end{array}$ & $\begin{array}{c}\% \text { of Patients } \\
\text { Affected }(95 \% \mathrm{Cl})\end{array}$ & $1^{2}$ & P Value* \\
\hline Distal osteotomy & $12(27.3 \%)$ & 955 (34.2\%) & 24 & $1.9(0.3-4.9)$ & $80 \%$ & $<0.001$ \\
\hline Shaft osteotomy & $10(22.7 \%)$ & $654(23.4 \%)$ & 18 & $2.3(1-4.2)$ & $40 \%$ & 0.1 \\
\hline Shaft and Akin osteotomies & $2(4.5 \%)$ & 143 (5.1\%) & 23 & $16(10.5-22.4)$ & $0 \%$ & 0.66 \\
\hline First TMT arthrodesis $†$ & $2(4.5 \%)$ & $154(5.5 \%)$ & 10 & $6.4(3.1-10.8)$ & $0 \%$ & 0.68 \\
\hline Other & $2(4.5 \%)$ & 109 (3.9\%) & 23 & $21.1(14-29.2)$ & $0 \%$ & 0.88 \\
\hline Total & 44 & 2,793 & 146 & $3.8(2.2-5.9)$ & $80 \%$ & $<0.001$ \\
\hline
\end{tabular}


The Journal of Bone \& Joint SURgery $\cdot$ JBjS.org Volume 100-A · Number $18 \cdot$ SePtember 19, 2018

Unfavorable Outcomes Following Surgical Treatment of Hallux Valgus Deformity

TABLE XV Rate of Postoperative Hallux Varus Deformity by Surgery Type

\begin{tabular}{|c|c|c|c|c|c|c|}
\hline Surgery Type & $\begin{array}{l}\text { No. of Studies } \\
\qquad(\mathrm{N}=117)\end{array}$ & $\begin{array}{l}\text { No. of Patients } \\
\qquad(\mathrm{N}=7,904)\end{array}$ & $\begin{array}{c}\text { Total No. of } \\
\text { Patients Affected }\end{array}$ & $\begin{array}{c}\% \text { of Patients } \\
\text { Affected }(95 \% \mathrm{Cl})\end{array}$ & $\mathrm{I}^{2}$ & P Value* \\
\hline Distal osteotomy† & 45 (38.5\%) & $3,711(47.0 \%)$ & 45 & $0.7(0.3-1.3)$ & $70 \%$ & $<0.001$ \\
\hline Shaft osteotomy & $10(8.5 \%)$ & $574(7.3 \%)$ & 17 & $1.8(0.4-4.3)$ & $70 \%$ & 0.003 \\
\hline Joint hemiresection & $5(4.3 \%)$ & $269(3.4 \%)$ & 10 & $2.9(0.4-7.7)$ & $70 \%$ & 0.022 \\
\hline $\begin{array}{l}\text { Proximal and Akin } \\
\text { osteotomies }\end{array}$ & $4(3.4 \%)$ & $356(4.5 \%)$ & 17 & $3.2(0.6-8.4)$ & $80 \%$ & 0.016 \\
\hline First TMT arthrodesis§ & $2(1.7 \%)$ & $82(1.0 \%)$ & 2 & $2.9(1.2-5.5)$ & $0 \%$ & 0.73 \\
\hline Other & $11(9.4 \%)$ & 748 (9.5\%) & 19 & $1.2(0.2-3)$ & $70 \%$ & 0.001 \\
\hline Total & 117 & 7,904 & 216 & $1.83(1.26-2.51)$ & $80 \%$ & $<0.001$ \\
\hline
\end{tabular}

*Cochran test for heterogeneity of studies within each surgery type. †Surgery type with lowest value. キSurgery type with highest value. $\S \mathrm{TMT}=$ tarsometatarsal.

findings. First, most of these procedures were combined with a lateral soft-tissue release. The combination of an aggressive medial eminence resection with a substantial soft-tissue release and tight medial collateral ligament closure can increase the potential for postoperative problems, including the development of hallux varus. Second, the case-weighted average year of publication for these procedures was 1989. The procedures were performed an average of 6 years prior to publication, well before internal fixation was widely used in treating HV, and most likely involved patients with large deformities needing substantial dissection and bone resection to obtain a satisfactory intraoperative reduction. Today, with other approaches being more commonly used, the patients in those earlier series might very well not be considered for a "simple" bunionectomy.

Similarly, joint hemiresection to treat $\mathrm{HV}$ is no longer commonly reported. The case-weighted average year of publication for the included articles on hemiresection of the first metatarsophalangeal joint for the treatment of HV was 1996, with an average follow-up of 6 years. On average, these procedures were performed during or before 1990. The ultimate dissatisfaction with this procedure and "simple" bunionectomy may be a key reason that other general types of procedures have been reported more frequently in the past 2 decades. Both procedures, simple bunionectomy and joint hemiresection, are associated with a higher-than-average failure rate and are mostly of historical interest, as they fail to acknowledge the complex mechanics of the foot and of HV deformity.

The use of internal fixation is associated with secondary procedures for hardware removal. As expected, the more hardware that is used, the higher the rate of removal. Adding an Akin procedure to a shaft osteotomy procedure is associated with a higher rate of undergoing a subsequent procedure to remove hardware. However, the decision to remove hardware depends on the preferences of the patient and the surgeon; this review does not have the ability to fully elucidate the factors behind these decisions, which could be unrelated to the amount of hardware used.

TABLE XVI Weighted Correlation Between Preoperative Radiographic Parameters and Postoperative Outcomes*

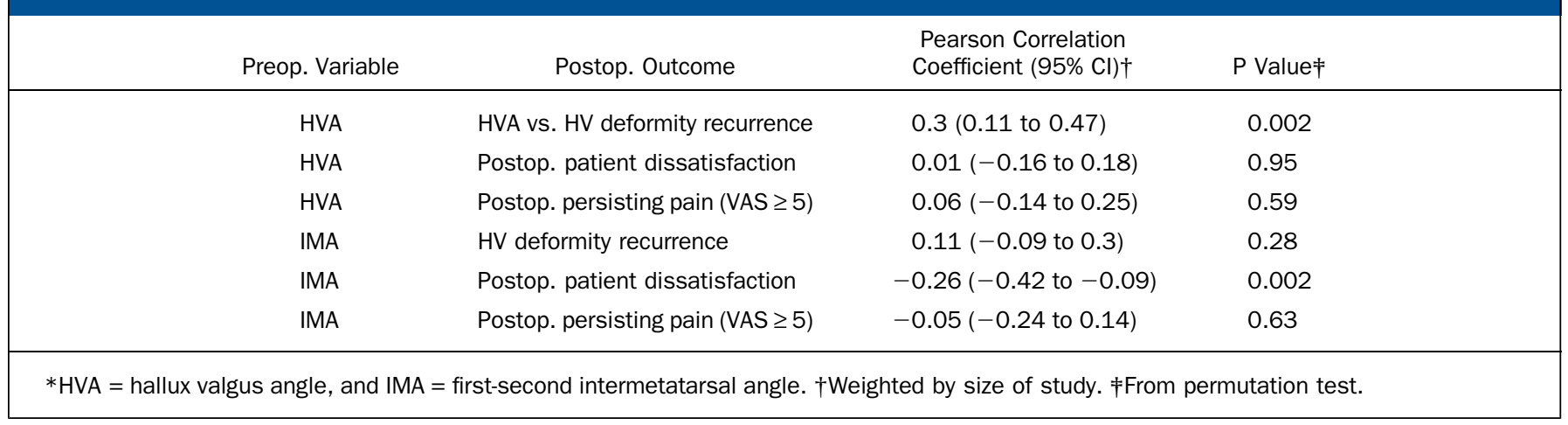


The Journal of Bone \& Joint Surgery $\cdot$ JbJs.org Volume 100-A · Number $18 \cdot$ September 19, 2018
Unfavorable Outcomes Following Surgical Treatment of Hallux Valgus Deformity
This study was clearly limited by the quality of the source literature, which is dominated by single-surgeon retrospective case series, and by the long period of time covered, with different data-quality standards. The aggregation of data cannot control for the technical skill of the surgeon, the degree of deformity, or the complexity of the cases treated. As a result, conclusions should be interpreted with caution to reflect this uncertainty. This study is further limited by language, as there undoubtedly were valuable reports in languages that we were unable to critically review. Overall, we found that HV surgery has been reported to have fairly consistent results and rates of complications or unfavorable outcomes. We were further limited by the grouping of procedures (e.g., distal or proximal metatarsal osteotomies) as clearly there are technical differences in how these are performed, and those differences may substantially affect outcomes. Similarly, grouping together series of cases with somewhat different approaches (for example, open and limited-incision distal first metatarsal osteotomies) is an additional limitation of the study. Although we found evidence of recent enthusiasm for less-invasive procedures for HV, we did not identify enough case series with sufficient follow-up for inclusion as a separate type of surgery. Future work should focus on the value of organizing and conducting prospective multicenter studies from which higherquality data can be abstracted.

\section{Appendix}

eA Tables describing the search strategy, the types of tools eA used for measuring satisfaction, and the characteristics of the included studies, as well as a supplementary reference list containing the included studies, are available with the online version of this article as a data supplement at jbjs.org (http:// links.lww.com/JBJS/E890).

Alexej Barg, $\mathrm{MD}^{1}$

Joshua R. Harmer, BS ${ }^{1}$

Angela P. Presson, $\mathrm{PhD}^{1}$

Chong Zhang, $\mathrm{MS}^{1}$

Mellanye Lackey, MSI $^{2}$

Charles L. Saltzman, $\mathrm{MD}^{1}$

${ }^{1}$ Department of Orthopaedics (A.B., J.R.H., and C.L.S.) and Division of Epidemiology, Department of Internal Medicine (A.P.P. and C.Z.), University of Utah, Salt Lake City, Utah

${ }^{2}$ Spencer S. Eccles Health Sciences Library, Salt Lake City, Utah

E-mail address for A. Barg: alexej.barg@hsc.utah.edu

E-mail address for C.L. Saltzman: charles.saltzman@hsc.utah.edu

ORCID iD for A. Barg: 0000-0003-0276-6782

\section{References}

1. Coughlin MJ. Hallux valgus. J Bone Joint Surg Am. 1996 Jun;78(6):932-66.

2. Easley ME, Trnka HJ. Current concepts review: hallux valgus part 1: pathomechanics, clinical assessment, and nonoperative management. Foot Ankle Int. 2007 May;28(5):654-9.

3. Nix S, Smith M, Vicenzino B. Prevalence of hallux valgus in the general population: a systematic review and meta-analysis. J Foot Ankle Res. 2010 Sep 27;3:21. 4. Perera AM, Mason L, Stephens MM. The pathogenesis of hallux valgus. J Bone Joint Surg Am. 2011 Sep 7;93(17):1650-61.

5. Easley ME, Trnka HJ. Current concepts review: hallux valgus part II: operative treatment. Foot Ankle Int. 2007 Jun;28(6):748-58.

6. Robinson AH, Limbers JP. Modern concepts in the treatment of hallux valgus. J Bone Joint Surg Br. 2005 Aug;87(8):1038-45.

7. Bock P, Kluger R, Kristen KH, Mittlböck M, Schuh R, Trnka HJ. The Scarf osteotomy with minimally invasive lateral release for treatment of hallux valgus deformity: intermediate and long-term results. J Bone Joint Surg Am. 2015 Aug 5;97(15): 1238-45.

8. Coughlin MJ, Jones CP. Hallux valgus and first ray mobility. A prospective study. J Bone Joint Surg Am. 2007 Sep;89(9):1887-98.

9. Glazebrook M, Copithorne P, Boyd G, Daniels T, Lalonde KA, Francis P, Hickey M. Proximal opening wedge osteotomy with wedge-plate fixation compared with proximal chevron osteotomy for the treatment of hallux valgus: a prospective, randomized study. J Bone Joint Surg Am. 2014 Oct 1;96(19):1585-92.

10. Park YB, Lee KB, Kim SK, Seon JK, Lee JY. Comparison of distal soft-tissue procedures combined with a distal chevron osteotomy for moderate to severe hallux valgus: first web-space versus transarticular approach. J Bone Joint Surg Am. 2013 Nov 6;95(21):e158.

11. Lee WC, Kim YM. Correction of hallux valgus using lateral soft-tissue release and proximal Chevron osteotomy through a medial incision. J Bone Joint Surg Am. 2007 Oct;89(Suppl 3):82-9.

12. Chen JY, Lee MJ, Rikhraj K, Parmar S, Chong HC, Yew AK, Koo KO, Singh Rikhraj I. Effect of obesity on outcome of hallux valgus surgery. Foot Ankle Int. 2015 Sep; 36(9):1078-83. Epub 2015 Apr 16.
13. Coetzee JC. Scarf osteotomy for hallux valgus repair: the dark side. Foot Ankle Int. 2003 Jan;24(1):29-33.

14. Givissis P, Karataglis D, Christodoulou A, Terzidis I, Pournaras J. Wilson osteotomy stabilised by means of internal fixation for the treatment of hallux valgus. Acta Orthop Belg. 2004 Feb;70(1):57-63.

15. Moher D, Shamseer L, Clarke M, Ghersi D, Liberati A, Petticrew M, Shekelle P, Stewart LA; PRISMA-P Group. Preferred reporting items for systematic review and meta-analysis protocols (PRISMA-P) 2015 statement. Syst Rev. 2015 Jan $1 ; 4: 1$.

16. Coleman BD, Khan KM, Maffulli N, Cook JL, Wark JD; Victorian Institute of Sport Tendon Study Group. Studies of surgical outcome after patellar tendinopathy: clinical significance of methodological deficiencies and guidelines for future studies. Scand J Med Sci Sports. 2000 Feb;10(1):2-11.

17. Maffulli N, Papalia R, Palumbo A, Del Buono A, Denaro V. Quantitative review of operative management of hallux rigidus. Br Med Bull. 2011;98:75-98. Epub 2011 Jan 14.

18. Chahla J, Piuzzi NS, Mitchell JJ, Dean CS, Pascual-Garrido C, LaPrade RF, Muschler GF. Intra-articular cellular therapy for osteoarthritis and focal cartilage defects of the knee: a systematic review of the literature and study quality analysis. J Bone Joint Surg Am. 2016 Sep 21;98(18):1511-21.

19. Viechtbauer $W$. Conducting meta-analyses in $\mathrm{R}$ with the metafor package. J Stat Softw. 2010;36(3):1-48.

20. Rücker G, Schwarzer G, Carpenter J, Olkin I. Why add anything to nothing? The arcsine difference as a measure of treatment effect in meta-analysis with zero cells. Stat Med. 2009 Feb 28;28(5):721-38.

21. DerSimonian R, Laird N. Meta-analysis in clinical trials. Control Clin Trials. 1986 Sep;7(3):177-88.

22. Sitzia J. How valid and reliable are patient satisfaction data? An analysis of 195 studies. Int J Qual Health Care. 1999 Aug;11(4):319-28.

23. Wiewiorski M, Barg A, Hoerterer $\mathrm{H}$, Voellmy $\mathrm{T}$, Henninger HB, Valderrabano $\mathrm{V}$. Risk factors for wound complications in patients after elective orthopedic foot and ankle surgery. Foot Ankle Int. 2015 May;36(5):479-87. Epub 2014 Dec 30. 